\title{
Going Beyond Academic Integrity Might Broaden our Understanding of Plagiarism in Science Education: A Perspective from a Study in Brazil*
}

\author{
CHRISTIANE C. SANTOS ${ }^{1,3}$, PATRÍCIA S. DOS SANTOS ${ }^{2}$, MAURÍCIO C. SANT'ANA ${ }^{4}$, \\ HATISABURO MASUDA ${ }^{1,2}$, MONICA B. BARBOZA ${ }^{2}$ and SONIA M.R. VASCONCELOS ${ }^{1,2}$
}

\author{
${ }^{1}$ Science Education Program, Institute of Medical Biochemistry Leopoldo de Meis (IBqM), \\ Federal University of Rio de Janeiro (UFRJ), 21941-902 Rio de Janeiro, RJ, Brazil \\ ${ }^{2}$ Professional Masters Program in Science Education, Institute of Medical Biochemistry Leopoldo de Meis \\ (IBqM), Federal University of Rio de Janeiro (UFRJ), 21941-902 Rio de Janeiro, RJ, Brazil \\ ${ }^{3}$ Pedro II School, Campo de São Cristóvão, 177, $3^{\circ}$ Andar, São Cristóvão, 20921-903 Rio de Janeiro, RJ, Brazil \\ ${ }^{4}$ The National Regulatory Agency for Private Health Insurance and Plans (ANS), Av. Augusto Severo, \\ nº 84, Edifício Barão de Mauá, Bairro Glória, 20021-040 Rio de Janeiro, RJ, Brazil
}

Manuscript received on July 20, 2016; accepted for publication on November 4, 2016

\begin{abstract}
Fostering innovation and creativity is a priority in the science and education policy agenda of most countries, which have advocated that innovative minds and processes will boost scientific and economic growth. While our knowledge society has embraced this view, fostering creativity is among the major challenges faced by educators and policymakers. For example, plagiarism, which may be considered a form of imitation and repetition, is a global concern at schools and universities. However, most discussions focus on academic integrity, which, we believe, leaves some gaps in the approach to the problem. As part of an ongoing project on plagiarism, science and education policy, we show results from a survey sent to 143 high-school science teachers at one of the most highly regarded federal schools in Brazil. Among respondents $(\mathrm{n}=42)$, about $50 \%$ admit that students plagiarize in assignments. Additionally, many of these educators suggest that the way biology, chemistry and physics are taught at school stimulates more repetition than creativity. Our findings are consistent with the need for a broader perspective on plagiarism and with initiatives to stimulate creativity and critical thinking among students. Although we offer a perspective from Brazil, it may illuminate current discussions on plagiarism, particularly in emerging countries.
\end{abstract}

Key words: research integrity, plagiarism, science education, science policy, rote learning.

\section{INTRODUCTION}

Fostering innovation and creativity is a high priority for education in our knowledge economy

Correspondence to: Sonia Maria Ramos de Vasconcelos E-mail: svasconcelos@bioqmed.ufrj.br

* Contribution to the centenary of the Brazilian Academy of Sciences.
(Florida et al. 2015, Liu and Lin 2014, Sleuwaegena and Boiardia 2014). Globally, it seems that we are experiencing a creativity arms race where creative human capital will gradually define a new geography of knowledge and innovation (Flew 2010, Florida 2002). This is a reasonable assumption if we consider that "in place of the natural resources and large-scale industries that 
powered the growth of industrial capitalism, the growth of creative capitalism turns on knowledge, innovation, and talent" (Florida et al. 2015). For the science and education policy agenda of most countries, it has been advocated that innovative minds and processes will boost scientific and economic growth (Hasan and Tucci 2010, OECD 2013a, 2015a). While our knowledge economy has embraced this view, the pursuit of creativity and innovation is not harmonized with a culture of three R's - rote, repetition, and regurgitation - at school (Dahlin and Walkins 2000, Hammond et al. 2010). In fact, repetition and rote-learning strategies are part of the education culture (Mayer 2002, Novak 2003, Hudson 2013). In this culture, plagiarism, which may be considered a particular form of repetition of knowledge, has been discussed for years.

That detection of plagiarism practices is a global concern seems to be a fact (Bohannon 2014, Bretag 2013). According to the coordinator of the project "Plagiarism or Creativity Teaching Innovation Versus Stealing" (Mascitti 2012), supported by the European Commission, "the cut, copy and paste boom is becoming normalized". However, the reasons for a supposed growth in this practice are only partially understood. There is some discussion over, for example, cultural assumptions and attitudes toward plagiarism, which point to sensitive issues far from trivial for educators. As Pennycook (1996) argues, “...the way ownership and creativity are understood within European and U.S. contexts needs to be seen as a very particular cultural and historical development." Introna et al. (2003) report that "from the experiences of Lancaster University staff in the Management School and the Computing Department it is clear that there are different levels of understanding of plagiarism between different cultures.".

In this arena, the limits of borrowing the intellectual creations of others are not always clear in academia and at school. This factor adds to the concerns of those who teach science and technology, both in established and emerging scientific powers, including Brazil. The country accounts for more than two-thirds of the scientific output of Latin America, which is 4\% of the world's share (Noorden 2014). According to data from Scimago Journal and Country Rank (Thomson Reuters 2015), Brazil ranks $13^{\text {th }}$ out of 231 countries listed in 2015 with at least one indexed publication. Despite the country's current economic hurdles (Gibney 2015), Brazil continues to have an enormous potential to improve its scientific and technological base (Lema et al. 2015) and, as in many other countries, increasing the number of scientists and engineers is among the goals (Gupta et al. 2013). Those who teach science at school are expected to join this national effort. Among the difficulties to be faced is the low performance of Brazilian students in international assessments, such as the Program for International Student Assessment (PISA), organized by the Organization for Economic Cooperation and Development (OECD).

The PISA assesses reading, mathematical and scientific literacy- a concept "... concerned with the capacity of students to apply knowledge and skills in key subject areas and to analyse, reason and communicate effectively as they pose, solve and interpret problems in a variety of situations." (OECD 2009a). The exam, applied across more than 60 countries (OECD 2014a), assesses the extent to which 15-year old students completing compulsory education "have acquired some of the knowledge and skills essential for full participation in the knowledge society." (OECD 2009b). As for Brazilian students, enrolment rates in schools for 15 -year-olds grew from $65 \%$ in 2003 to $78 \%$ in 2012 (OECD 2014a). However, there is a 92\% enrolment rate in education up to age 14 , but their performance in all competencies is considerably lower than that of their peers from other countries (Arnold and Jalles 2014). 
Concerning science and reading, the following comment details PISA scores for Brazil:

“... Some $61 \%$ of Brazilian students are low performers in science, meaning that, at best, they can present scientific explanations that are obvious and respond to explicit scientific evidence. Only $0.03 \%$ are top performers, meaning that they can identify, express, explain and apply scientific knowledge in a variety of complex life situations. In reading, the results are similar." (Knobel 2014)

It is worth pointing out that although PISA tests results have been used for many institutions as proxy for educational achievement and informed education policy discussions, there is mounting criticism over the Program (Sjøberg 2007, Andrews et al. 2014). Among the criticisms is that the Program allows private corporations to design tests and have access to global related data. This situation would make PISA "closer to crossing the line that separates commercial interest for expanded markets" and "neutral and trustworthy independent measurements of the health of education systems" (Strauss 2015). Strauss (2015) acknowledges the importance of PISA for the global educational arena, but points out that "some experts claim there are major technical flaws with the items that make up PISA tests, with how the tests are administered, with how samples of students are determined in some countries (especially in Asia)...". However, apart from the Program's shortcomings, it seems to be generally accepted that the performance of students of a given country somewhat reflects its educational resources and economic standing (OECD 2014b, Meroni et al. 2015).

Concerning Brazil, the low performance of its students in PISA may be looked at as a snapshot of the challenges lying ahead for education in the country. In The Global Competitiveness Report 2014-2015 of the World Economic Forum (2014), Brazil ranks 18 in primary education enrollment while it ranks 126 for quality of primary education, out of a total of 144 countries. A combination of factors may explain this situation, and pedagogical practices may be partially to blame. In this scenario, neglecting plagiarism practices among students may compound the problem, if we assume that these practices stimulate the culture of rote learning, or rather the three R's at school (Garvin-Doxas et al. 2007, Schultz 2012). As we have suggested, this culture seems to be at odds with initiatives to promote scientific literacy and innovation, not to mention academic integrity (Mascitti 2012, Vasconcelos et al. 2015).

Researchers and educators tend to agree that plagiarism is a form of academic dishonesty, and giving credit where credit is due is expected in the scientific culture. In academia, using ideas, words, and other intellectual property as if they were one's own is usually addressed as an ethical breach. Concerning science education, Elgin (2011) states that "all science education aims at inculcating an understanding of science", and "the dishonesty of falsification, fabrication, and plagiarism is not an accidental feature of practices whose scientific objection ability lies elsewhere. Their dishonesty thwarts science's goal."

In the education arena, plagiarism practices among students are, therefore, usually seen through the lens of academic integrity and associated issues. The literature has mostly focused on frequency of cases and reasons alleged by students/authors as well as cultural and technological factors underlying the practice (McCabe 2005, Gabriel 2010, Thomas and Sassi 2011, Khoza 2015, Sureda-Negre et al. 2015). Increasingly, however, attention to learning factors underlying plagiarism has grown among educators (Carroll 2007a, Tulley-Pitchford 2012, Roberts 2008). Carroll (2007b), for example, claims that "by focusing on stopping cheating, we risk inappropriate handling in the vast majority of cases where learning is the central issue." Also, Tulley-Pitchford (2012) says that "rather 
than deliberate dishonesty, plagiarism is often unintentional and due to misunderstandings by students." In this article, we believe the perspective we offer is consistent with these claims and raises objective and contemporary questions that might be worth considering by both science teachers and policymakers. These questions go beyond the ethical dimension of the problem; they add to existing challenges plagiarism poses for all of those committed to education and to fostering a scientific culture in our knowledge society.

Under this assumption, we have drawn upon the perceptions about plagiarism, and related pedagogical questions, of 42 high-school science teachers at one of the most highly regarded federal schools in Brazil. While our perspective reflects the perceptions of a particular group of Brazilian respondents, concerns over plagiarism among students and over rote learning are not country specific (Roig 2001, Novak 2002, SutherlandSmith 2005, Educational Initiatives and Wipro 2011, Hardman 2015). As an intriguing title in The New York Times suggests, today, "plagiarism lines blur for students" (Gabriel 2010).

\section{MATERIALS AND METHODS}

This paper is part of an ongoing research project approved by the Research Ethics Committee (CEP) [Institutional Review Board - IRB in the US] at the Clementino Fraga Filho University Hospital of the Federal University of Rio de Janeiro (UFRJ). We conducted a survey targeted at a non-probabilistic purposeful sample of high-school teachers. We surveyed biology, chemistry and physics teachers $(n=143)$ at one of the most highly regarded federal schools in Brazil. This school currently has more than 5,000 high-school students enrolled, and it traditionally offers regular secondary education. The survey focuses mostly on teachers' perceptions of plagiarism as a concept, as a practice at school and as a means to make themselves revisit their formative roles in stimulating students' creativity and critical thinking. We used a semi-structured questionnaire that included two items related to informed consent. The survey form was divided into two sections: Section I, containing six demographic questions, and Section II, containing 28 content questions. The Likert scale was adopted for Section II, except for the last question. The survey was sent through email invitation (www. surveymonkey.com) and was available online for respondents from July to September 2014. For the survey, 57 respondents (those responding to at least one item of the survey) were recorded, but only $47(33 \%)$ started the survey in Section I. Among these respondents, we considered that 42 were valid, as those who provided only demographic information or did not agree with the consent form were excluded $(n=5)$ from the analysis.

The reliability of the Likert-type instrument was assessed measuring internal consistency through the calculation of Cronbach's alpha. This coefficient provides an estimate of scale reliability (Cronbach 1951, Santos 1999, Gliem and Gliem 2003, Maroco and Garcia- Marques 2006), or rather "... a function of the extent to which items in a test have high communalities and thus low uniquenesses. It is also a function of interrelatedness" though "...this does not imply unidimensionality or homogeneity" (Cortina 1993). Although alpha values need to be interpreted with caution (Boyle 1991, Cortina 1993, Clark and Watson 1995, Osburn 2000), the closer it is to 1.0 "the greater the internal consistency of the items in the scale" (Gliem and Gliem 2003). A Cronbach's alpha ranging from 0.60 to 0.80 is said to be acceptable (Shankman and Allen 2010). Clark and Watson (1995) reports that reliability of scales between 0.60 and 0.70 have been considered "good or adequate" by some authors. Yet, for the social sciences, an alpha of 0.70 seems to be a cut-off (Cortina 1993, Peterson 1994, Maroco and Garcia-Marques 2006). We obtained an alpha of 0.60 , which might be underestimated by the non-homogeneous nature of our survey items (Osburn 2000, Maroco and Garcia-Marques 2006). Given the nature of our questions and the 
correlation of ideas we aimed to explore in the survey, we did not make any attempt to increase the alpha value (0.60), such as changing the number of items considered for the analysis (Maroco and Garcia-Marques 2006). All items were retained for the overall interpretation of the survey results. As this is an exploratory step, and the survey is part of a larger project, we believe some sources of uncertainty will be clarified with additional data.

The alpha was calculated according to the following formula, using SPSS (Statistical Package for the Social Sciences) version 23:

$$
\alpha=\frac{N \cdot \bar{c}}{\bar{v}+(N-1) \cdot \bar{c}}
$$

where $\mathrm{N}$ is equal to the number of items, c-bar is the average inter-item covariance among items and $\mathrm{v}$-bar is the average variance.

\section{RESULTS AND DISCUSSION}

We explored the perceptions of 42 Brazilian highschool science teachers about plagiarism, related pedagogical issues, and the approach of these teachers to this practice among their students. Here, we focus on the major findings.

Our results suggest that dealing with plagiarism at school is a non-trivial issue for these respondents, if we consider inconsistencies in their perceptions about the very concept of plagiarism. When teachers were asked to indicate their level of agreement with the assertion Plagiarism can be defined as the use of somebody else's ideas and the appropriation of them without due credit to the source/authors (Figure 1), about 93\% of the respondents $(\mathrm{n}=42)$ agreed or partially agreed.

On their perceptions about the appropriation of words/text, about $95 \%$ of the respondents $(n=42)$ agreed or partially agreed (Figure 2) with the assertion that Plagiarism can be defined as the use of the written intellectual property of others (sentences/paragraphs, complete texts) without giving due credit. However, about $41 \%$ of the respondents $(\mathrm{n}=41)$ agreed or partially agreed that Verbatim copying (clone) from the Internet is not plagiarism as long as students cite the source (Figure 3).

For this assertion, we used the word "clone" to indicate that no quotation marks would be used for such textual borrowing. Cloning usually implies word-for-word copy without quotation marks (Plagiarism Today, 2012). The word clonagem [cloning], as originally used in the Portuguese version of the survey, indicates a severe form of borrowing word for word from a source. We

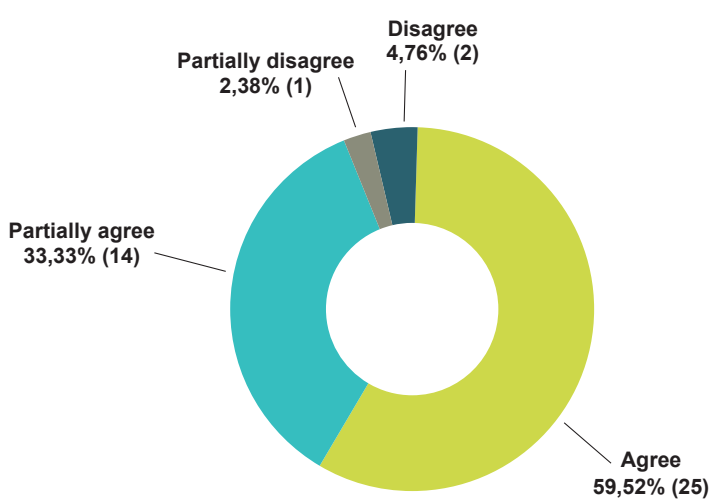

Figure 1 - Share of respondents' level of agreement with the assertion Plagiarism can be defined as the use of somebody else's ideas and the appropriation of them without due credit to the source/authors.

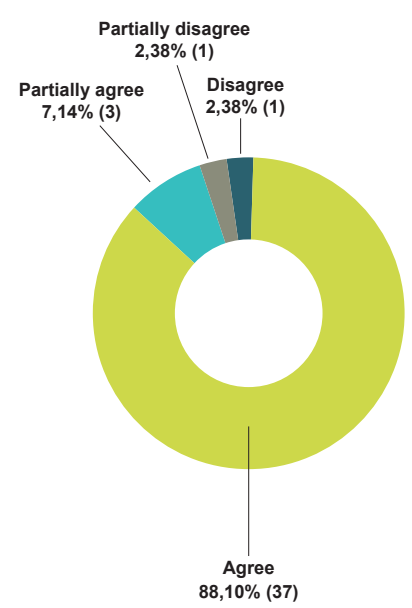

Figure 2 - Share of respondents' level of agreement with the assertion Plagiarism can be defined as the use of the written intellectual property of others (sentences/paragraphs, complete texts) without giving due credit. 


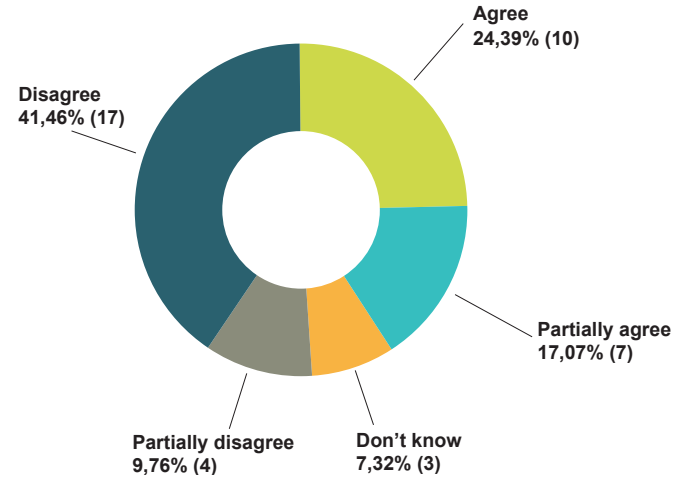

Figure 3 - Share of respondents' level of agreement with the assertion Verbatim copying (clone) from the Internet is not plagiarism as long as students cite the source.

thus find this result suggests some inconsistency between the agreement of our respondents with the concept of plagiarism and their actual practice when evaluating the problem. They may have doubts about what constitutes or should constitute plagiarism. But this is not an unexpected result. More than $50 \%$ of the respondents $(n=42)$ said that they did not receive or rarely received guidance on plagiarism in their undergraduate courses - though the percentage of those who say the same for graduate courses is smaller (about $33 \%$ ).

In fact, the inconsistency we noted between the concept of plagiarism and actual practice in the classroom does not seem to be a peculiarity of this sample of Brazilian teachers. Difficulty to identify plagiarism has been reported for teachers and students from different cultures and nations (Roig 1997, 2001, Pecorari 2003, Bretag 2013, Holt et al. 2014).

In the European report, "Impact of Policies for Plagiarism in Higher Education across Europe" (Glendinning 2013a), among a group of teachers surveyed in France, the ability to identify plagiarism was considered to be worrying. The same type of report for Germany (Glendinning $2013 b$ ) indicated that $44 \%$ of the teachers surveyed would like to have more training on avoidance of plagiarism and academic dishonesty. In our study, we find that notwithstanding the doubts of our respondents about plagiarism, this practice is part of their classroom reality, as can be suggested in Figure 4. It illustrates how often students plagiarize in writing assignments. Among the 41 teachers who responded when they were asked whether students plagiarize whenever they complete a writing assignment in their disciplines, 51\% answered always or almost always.

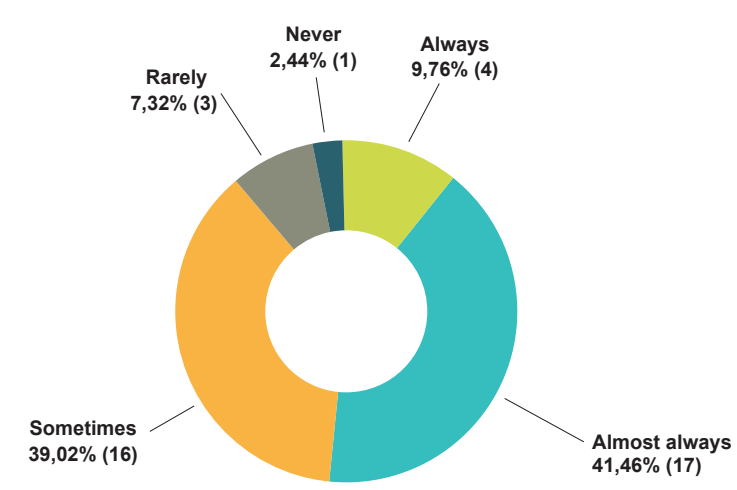

Figure 4 - Share of respondents' level of agreement with the assertion Students plagiarize whenever they complete a writing assignment in my discipline. ${ }^{1}$

This finding is not surprising and is consistent with previous survey results (Dupree and Sattler 2010) showing that $60 \%$ of 479 participants of a faculty survey responded that plagiarism on written assignments occurred often or very often at their institution. A report by the Josephson Institute, Center for Youth Ethics (2012), which surveyed more than 23,000 high-school students in public and private schools, showed that $32 \%$ of students said they plagiarized in assignments.

Although we cannot attribute our results solely to pedagogical practices, teachers agreed that the type of assignment required may stimulate repetition and lead to plagiarized responses. Almost $83 \%$ of respondents $(\mathrm{n}=41)$ agreed or partially agreed that this is the case (Figure 5). In their perceptions,

\footnotetext{
${ }^{1}$ For writing assignment, we used "trabalho de pesquisa escrito" in the Portuguese version of the question. This "trabalho" would be an essay-type assignment, including webbased research.
} 


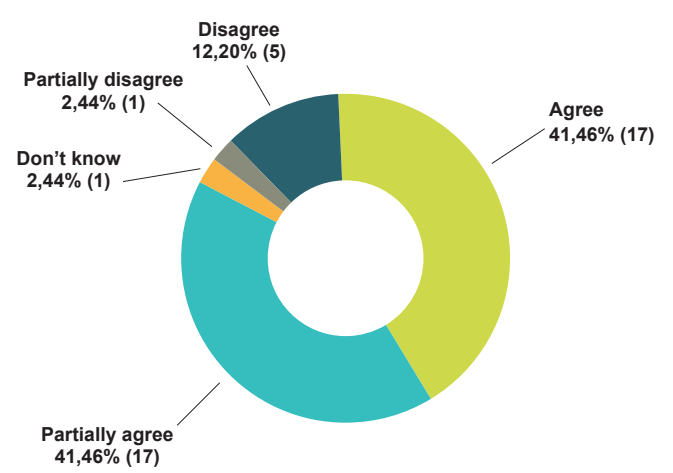

Figure 5 - Share of respondents' level of agreement with the assertion Teachers can stimulate plagiarism through the kind of assignment requested.

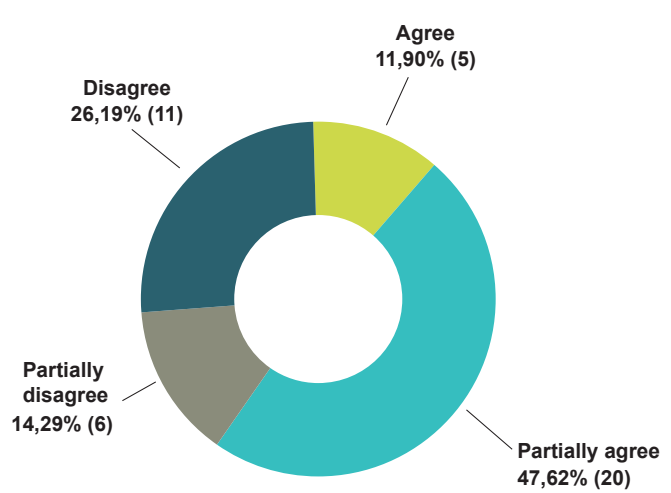

Figure 6 - Share of respondents' level of agreement with the assertion Plagiarism is a consequence of easy access to information on the Internet.

there seems to be a relationship between the type of assignment proposed and plagiarism practices. The percentage of those who perceive a direct relationship between plagiarism and easy access to the Internet is lower (about 59\% agreed or partially agreed), as can be seen in Figure 6.

The role of high school and university teachers in proposing assignments that can be more engaging and stimulate critical thinking has been of increasing concern (Carroll 2007a, Carroll and Zetterling 2009). Sisti (2007) and Anson (2003-2004), for example, indicate that university students may be critical of the assignments they are required to complete. The latter author reports on some students' assumptions that "assignments open themselves up to plagiarism- sometimes even induces it - in their insensitivity to students' writing and learning experiences".

Carroll and Zetterling (2009) have investigated the influence of assignments on students' plagiarism practices and suggested that memorizing or Googling may be prevented if teachers redesign the way they set questions and topics. The authors recommend, for example, that asking students to rank, plan, alter, categorize, produce, compare, select, rate or justify, among other action verbs, will reduce Googled answers. They add that "setting topics as questions", such as "Nanotechnology', 'genetically modified grain' and 'sustainable development' are just asking the student to find and copy". The responsibility of teachers in designing assignments that are more thought provoking seems to be in agreement with the idea that "in this brave new digital world, education has to catch up and develop new approaches to ensure that learning does not become a superficial, mechanistic process." (Mascitti 2012).

Concerning creativity at school, all respondents $(\mathrm{n}=42)$ agreed or partially agreed that plagiarism practices compromise students' development of creativity (Figure 7). Only about $24 \%$ of the 42 teachers agreed or partially agreed with the assertion that In Brazil, the pedagogical practices of teachers of biology, physics and chemistry

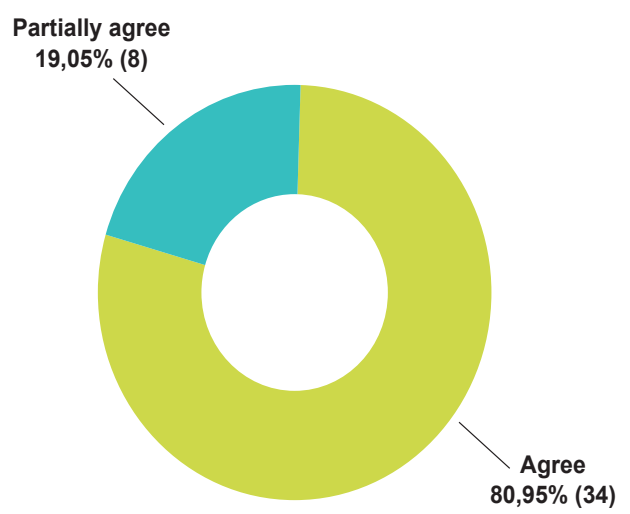

Figure 7 - Share of respondents' level of agreement with the assertion Plagiarism practices compromise students' development of creativity. 


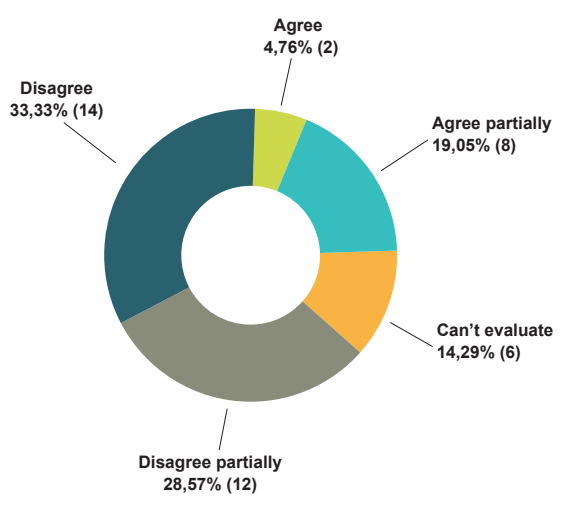

Figure 8 - Share of respondents' level of agreement with the assertion In Brazil, the pedagogical practices of teachers of biology, physics and chemistry stimulate more creativity than repetition.

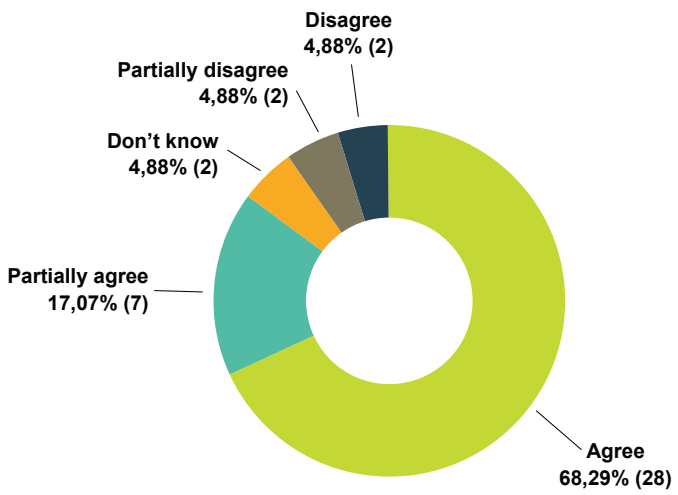

Figure 9 - Share of respondents' level of agreement with the assertion Plagiarism practices in high school compromise the development of the critical sense of students.

stimulate more creativity than repetition among students (Figure 8). The percentage is also high for those $(\mathrm{n}=41)$ who agree or partially agree that plagiarism practices in high school compromise the development of the critical sense of students (about 85\%) (Figure 9):

When it comes to learning, it is well known that repetition and memorization are part of the educational environment.

Concerning science education, Schönborn and Anderson (2008) reason that "assessing students' mindful memorization of knowledge is an important facet of conceptual understanding in the biomolecular sciences". According to the authors, "... it is a cognitive priori to building knowledge of a concept, one that precedes other 'higher-order' cognitive skills." For Garvin-Doxas et al. (2007), "although it seems easy to distinguish between rote memorization and higher levels of learning, there really is a great deal of any STEM [science, technology, engineering and mathematics] discipline that requires a certain amount of learning vocabulary definitions (much of which can be memorized), the ability to correctly label (again, something that can be memorized), and lists (which can be and usually are memorized)." On the other hand, pedagogical practices that stimulate repetition and memorization have shown important shortcomings. Hardman (2015) states that there is "growing recognition of amongst governments and development partners of the need to change underlying pedagogic practices that lead to the transmission of knowledge and rote learning."

Regarding rote learning and plagiarism, they appear to be linked in some interpretations, for example, that consider particular cultural features of Confucian cultures (Pennycook 1996). Foong and Daniel (2013) state that "in Malaysia, the Chinese vernacular schools follow a strict Confucian philosophy in the teaching and learning process. The teacher talks and the students listen". As explained by Dahlin and Walkins (2000), "in the West it is more common to associate memorizing with 'surface' and understanding with 'deep' approaches to learning." Yet, some authors challenge this view and claim that assumptions that rote learning and memorization in Confucian cultures equate with superficial understanding are stereotypes (Tran 2013, Tan 2015, Wang and Greenwood 2015). However, in "Plagiarism Plague Hinders China's Scientific Ambition" (Lim 2011), the co-author of the report "China: The Life Sciences Leader of 2020" says that the Chinese have to "lose some of the Confucian obedience of the university system, and have more give and take, and collaboration and aggressive debate, to move molecules forward, to move ideas forward". 
Although we could say that Brazilian and Confucian cultures have distinct legacies when it comes to education and learning approaches, Silva (2008) points out that

\begin{abstract}
"historically, from elementary school to university, the practice of copying of textual productions of others, partially or totally, omitting the source has been common. Therefore... the school distanced itself from the purpose of forming authors... who take responsibility for their say/writing..."
\end{abstract}

Looking at the Brazilian school environment, we believe that our small study, in light of the literature, is at least intriguing and leads us to think that thought-provoking assignments at school are not the rule. Indeed, Kemp and Chambers (2015) state that "the dual challenges of defining curriculum-relevant, scientifically informed goals and making these goals realistic and achievable within the practical constraints of the school day make successful lesson design a non-trivial task." When it comes to science education, these challenges are among those for teachers in Brazil. Schwartzman and Christophe (2009) have pointed out that Brazilian students do not need to be encouraged to recognize the importance of science, as they naturally value the scientific endeavor and are surrounded by its technological products. What they need is to understand science for real-world situations, and, as many other countries, Brazil does not ignore this fact.

As in many countries, there have been several outreach science education activities conducted by scientists to stimulate inquiry among students in Brazil. Araújo-Jorge et al. (2004) have already provided an overview of some of these efforts in the biological sciences, for example. Also, a National Network for Education and Science has promoted opportunities for thousands of students and teachers to participate in a scientific education program, for many years. This initiative was launched about 30 years ago by one of the most famous Brazilian scientists, Leopoldo de Meis. In 2012, the Network encompassed institutions from 13 different Brazilian states (Simões 2012). Now, it involves 23 institutions from 15 states. Professors and grads offer summer science courses for high-school students and teachers from public schools, focusing on inquiry-based activities to improve science learning and teaching in Brazil (Rede Nacional de Educação e Ciência: Novos Talentos da Rede Pública 2015). The Hands-on project, developed by the Brazilian Academy of Sciences, inspired by the Main à La Pâte of the French Academy of Sciences, is another important initiative (Schwartzman and Christophe 2009).

As we have previously argued, pedagogical practices alone would not explain the shortcomings in science education in Brazilian schools. We need to consider, for instance, data that offer some perspective from teachers' own assessment of their attitudes toward teaching and their working conditions in Brazil. According to "Key Findings from the Teaching and Learning International Survey" (TALIS) (OECD 2013b), a source of internationally comparable data on the learning environment and working conditions of schoolteachers, "almost all teachers in Brazil completed higher education, but they did not necessarily study the content, pedagogy and practices for the subjects they teach". The report also shows that "Brazil is among the TALIS countries in which teachers spend the most hours teaching per week".

According to the "Education at a Glance" report (OECD 2015b), Brazil needs to go a long way before achieving considerable improvements in its education system. When it comes to teachers' salaries, for instance, they are among the lowest in the world. Additionally, Brazilian teachers have to handle a much larger group of students per classroom when compared to that of the OECD average. That said, doing a good job that 
can stimulate the creativity of students involves a great deal of effort on the part of teachers working in Brazil. Yet, despite all hurdles, we believe these teachers are partially responsible for two interesting findings: (1) Brazil ranks 27, among the 60-plus countries listed for the percentage of students who report being happy at school. This type of data is intriguing as students from goodperforming countries in mathematics, science and reading are not necessarily among the happiest in

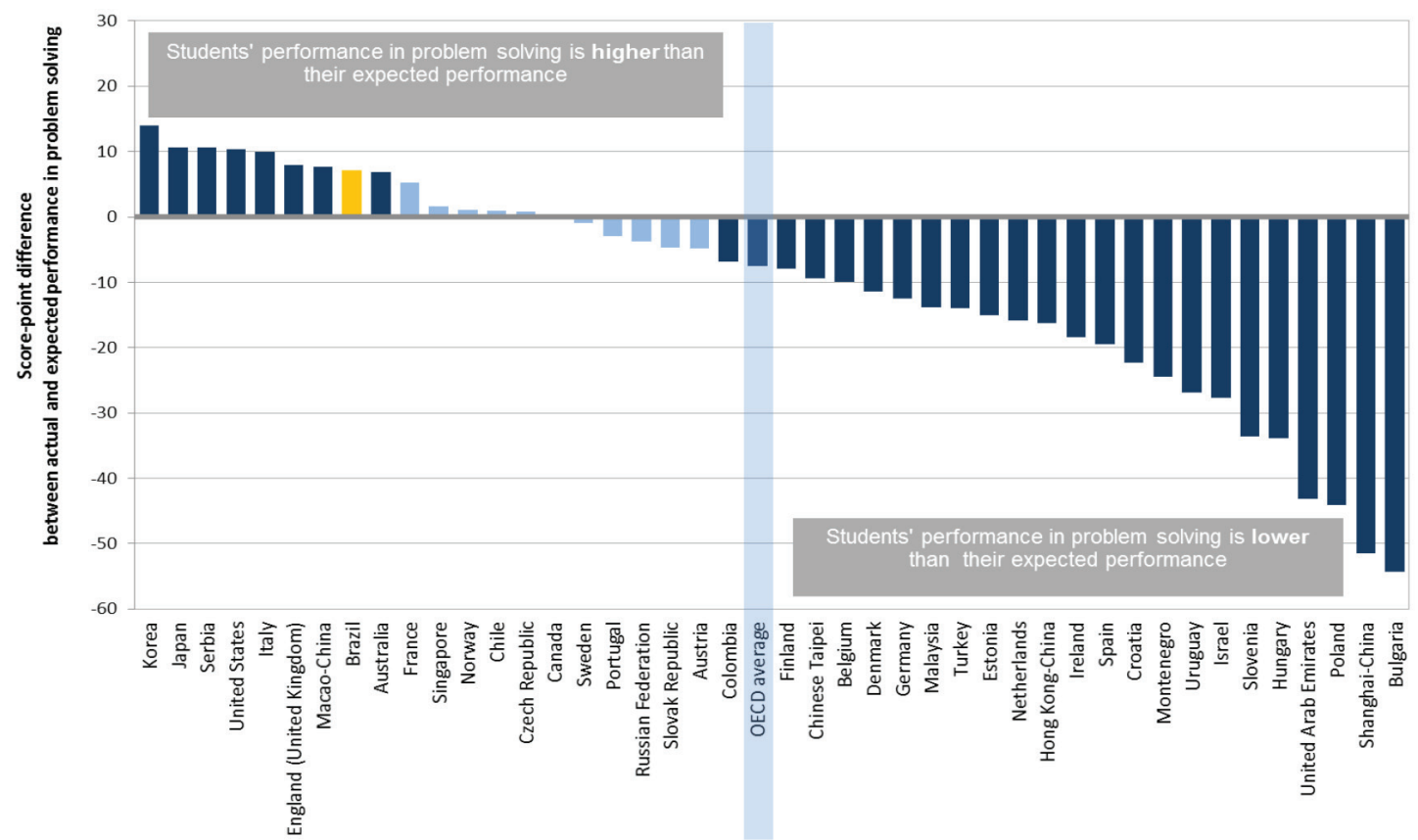

Figure 10 - Relative performance in creative problem-solving skills. "Each student's expected performance is estimated, using a regression model, as the predicted performance in problem solving given his or her score in mathematics, reading and science. Countries and economies are ranked in descending order of the score-point difference between actual and expected performance". Source: OECD, PISA 2012 Database; Table V.2.6 (OECD 2014d, e).

the school environment(OECD 2014c); (2) Also, Brazilian students do a little better in creative problem-solving skills (Figure 10). The country performs above the OECD average, together with the United Kingdom, the United States, Japan and other countries (OECD 2014d, e).

Given these results, we may guess that countries with better performance on problem-solving skills, as measured by the PISA, are not necessarily good at what more conventional questions on science, math and reading measure.

According to an OECD (2014c) report, "in Australia, Brazil, Italy, Japan, Korea, MacaoChina, Serbia, England (United Kingdom) and the
United States, students perform significantly better in problem solving, on average, than students in other countries who show similar performance in reading, mathematics and science...". The report adds that "compared to students of similar overall performance, students in Brazil, Ireland, Korea and the United States perform strongest on interactive problems that require students to uncover useful information...". Here, we cannot provide a clearcut explanation. Nevertheless, it is worth noting that there have been initiatives to foster more sciencing and problem-solving activities among Brazilian teachers and students, particularly in the last two decades (Simões 2012). Yet, they do not allow us 
to establish a cause-and-effect relationship. Our speculation is that social and cultural factors may play a role in this particular result (Fleith 2011).

Actually, addressing science much more as a verb than a noun at school has been emphasized for decades (McNairy 1985). This attitude is consistent with the assumption that students can learn science while trying to figure out answers for their questions at the school environment. This attitude would stimulate learners to receive real feedback on their ideas and not only have them simply checked by the teacher to see whether they correspond to what he/she expects to see (Duckworth 2006). Accordingly, there seems to be some consensus among educators that school performance may be improved if students go beyond recalling and/or memorizing facts (Mayer 2002, Lujan and DiCarlo 2006, Duckworth 2006). They should be evaluated by their ability to use concepts learned in different situations and/or solve problems (Mayer 2002, Crowe et al. 2008).

As for the association between memorization and plagiarism in assessments, a link between the nature of assessments and the amount of plagiarism among a group of higher-education students in France has been reported (Glendinning 2013a). It was found that "an assessment regime with $100 \%$ examinations would not provide equivalent opportunities for students to plagiarise as a programme with $100 \%$ assessment by coursework". On the other hand, a regime relying mostly on examinations may stimulate memorization and rote learning (Glendinning 2013a).

Overall, regarding science teaching in high school, our results corroborate the idea that students should be increasingly motivated to do inquirybased activities, solve problems, discriminate among ideas, and make choices based on criteria and reasoned arguments (Krathwohl 2002, Mayer 2002, Novak 2003, Pavesi et al. 2008, Lemons and Lemons 2013). As already demonstrated in many studies (Chinn and Malhotra 2002, Osborne and
Dillon 2008, Blanchard et al. 2009, Gerard et al. 2010), science courses should engage students in higher-order thinking and avoid "the recall of factual information which often leads teachers into a pedagogy which emphasizes rote learning." (Osborne and Dillon 2008).

Currently, further research is underway in our group to identify the extent to which pedagogies that emphasize such learning outcome may stimulate plagiarism among students. So far, our results lead us to believe that such pedagogical practices may create a vulnerability for educators to tackle plagiarism practices at school. For education in Brazil, we find that the perceptions of the science teachers surveyed are worth considering for at least two reasons: (1) Many of these respondents were former students trained at major graduate programs in the sciences at federal and state universities in Brazil - would their views on plagiarism be similar to those of colleagues in other public and private institutions? (2) These respondents teach science at a highly regarded federal school with more than 5,000 high-school students enrolled should broader discussions and approaches to plagiarism practices have a formative role to play in the academic and professional careers of these students?

\section{CONCLUSIONS}

Notwithstanding the limitations of our study, which does not allow us to make general claims, the questions we raise might broaden the perspective currently taken on plagiarism at school. In light of the literature we have drawn upon, the scenario we describe might reveal a blind spot in current discussions of the problem. This is a reasonable claim when we consider that the bulk of the literature addressing plagiarism at school is ethics related. We believe we need to expand on this approach, going beyond academic integrity issues. As we have described, plagiarism practices are part of our 
educational environment. However, gaps remain in educators' and policymakers' understanding of the extent to which the culture of rote learning, or the three R's, may stimulate such practices.

Here, we have shown that some countries in the European Union and the US, for example, have demonstrated a pro-active attitude toward addressing plagiarism in higher and secondary education. These concerns are aligned with the development of innovation policies at their institutions. Emerging countries such as Brazil, which has made great efforts to foster innovation and creativity in science and technology, is likely to benefit from devoting more attention to plagiarism and the reasons underlying this practice at school. Particularly for this country, we believe that a more comprehensive understanding of the problem at the basic education level is timely.

\section{ACKNOWLEDGMENTS}

We thank Coordenação de Aperfeiçoamento de Pessoal de Nível Superior (CAPES) for the financial support for the doctoral thesis of Christiane C. Santos, the first author. We also thank the members of the Doctoral Forum of the $4^{\text {th }}$ World Conference on Research Integrity (Rio, 2015) for providing valuable feedback on the project.

\section{REFERENCES}

ANDREWS P ET AL. 2014. OECD and PISA tests are damaging education worldwide - academics. The Guardian, May 06, 2014.

ANSON CM. 2003-2004. Student plagiarism: are teachers part of the solution or part of the problem? Essays on Teaching Excellence - Toward the Best in the Academy 15(1).

ARAÚJO-JORGE T. ET AL. 2004. Microscopy images as interactive tools in cell modeling and cell biology education. Cell Biol Edu 3: 99-110.

ARNOLD J AND JALLES J. 2014. Dividing the Pie in Brazil: Income Distribution, Social Policies and the New Middle Class. OECD Economics Department Working Papers, No. 1105, OECD Publishing, Paris. Available at: http:// www.oecd-ilibrary.org/economics/dividing-the-pie-in- brazil-income-distribution-social-policies-and-the-newmiddle-class_5jzb6w1rt99p-en.

BLANCHARD MR, SOUTHERLAND SA and GRANGER EM. 2009. No silver bullet for inquiry: Making sense of teacher change following an inquiry-based research experience for teachers. Sci Educ 93(2): 322-360.

BOHANNON J. 2014. Study of massive preprint archive hints at the geography of plagiarism. Science Insider, Dec 11, 2014.

BOYLE GJ. 1991. Does item homogeneity indicate internal consistency or item redundancy in psychometric scales? Pers Individ Dif 12(3): 3291-294.

BRETAG T. 2013. Challenges in addressing plagiarism in education. PLoS Med 10(12): e1001574.

CARROLL J. 2007a. A Handbook for Deterring Plagiarism in Higher Education, $2^{\text {nd }}$ ed., Oxford: The Oxford Centre for Staff and Learning Development, $132 \mathrm{p}$.

CARROLL J. 2007b. I'm fed up with people treating plagiarism and cheating as the same thing. Assessment Perspectives. ASKe Pedagogy Research Centre. Available at: https://www.brookes.ac.uk/aske/documents/CarrolJ_07_\%20PerspectivePaper.pdf.

CARROLL J AND ZETTERLING C-M. 2009. Guiding students away from plagiarism. Stockholm: KTH Learning Lab, 83 p. Available at: https://www.kth.se/polopoly_ fs/1.656375!/Guidingstudents $\% 20$ away $\% 20$ from $\% 20$ plagarism.pdf.

CHINN CA AND MALHOTRA B. 2002. Epistemologically authentic inquiry in schools: a theoretical framework for evaluating inquiry tasks. Sci Educ 86(2): 175-218.

CLARK LA AND WATSON D. 1995. Constructing validity: Basic issues in objective scale development. Psychol Assessment 7(3): 309-319.

CORTINA J. 1993. What is coefficient alpha: an examination of theory and applications. J Appl Psychol 78: 98-104.

CRONBACH LJ. 1951. Coefficient alpha and the internal structure of tests. Psychometrika 16(3): 297-334.

CROWE A, DIRKS C AND WENDEROTH MP. 2008. Biology in Bloom: implementing Bloom's Taxonomy to enhance student learning in Biology. CBE Life Sci Educ 7(4): 368-381.

DAHLIN B AND WALKINS D. 2000. The role of repetition in the processes of memorising and understanding: a comparison of the views of German and Chinese secondary school students in Hong Kong. Brit J Educ Psychol 70(1): $65-84$

DUCKWORTH E. 2006. The having of wonderful ideas and other essays on teaching and learning. New York: Teachers College Press, 207 p.

DUPREE D AND SATTLER S. 2010. Office of Planning and Assessment. Texas Tech University: McCabe Academic Integrity Survey Report. 
EDUCATIONAL INITIATIVES AND WIPRO. 2011. Quality education study. Educational Initiatives and Wipro. Available at: http:/www.ei-india.com/wp-content/ uploads/2012/07/Executive_Summary-Low_ResolutionQES1.pdf.

ELGIN C. 2011. Science, ethics and education. Theor Res Educ 9(3): 251-263.

FLEITH DS. 2011. Creativity in the Brazilian culture. ORPC 4(3). Available at: http://dx.doi.org/10.9707/23070919.1037.

FLEW T. 2010. Toward a cultural economic geography of creative industries and urban development: introduction to the special issue on creative industries and urban development. Inform Soc 26(2): 85-91.

FLORIDA R. 2002. The rise of the creative class: and how it's transforming work, leisure, community and everyday life. Toronto: Basic Books, 434 p.

FLORIDA R, MELLANDER C AND KING K. 2015. The global creativity index. The Martin Prosperity Institute. University of Toronto, $68 \mathrm{p}$.

FOONG C AND DANIEL E. 2013. Students' argumentation skills across two socio-scientific issues in a Confucian classroom: Is transfer possible? Int J Sci Educ 35(14): 2331-2355.

GABRIEL T. 2010. Plagiarism lines blur for students in digital age. The New York Times, August 1, 2010.

GARVIN-DOXAS K, KLYMKOWSKY M AND ELROD S. 2007. Building, using, and maximizing the impact of concept inventories in the biological sciences: report on a National Science Foundation sponsored conference on the construction of concept inventories in the biological sciences. CBE Life Sci Educ 6(4): 277-282.

GERARD LF, SPITULNIK M AND LINN MC. 2010. Teacher use of evidence to customize inquiry science instruction. $\mathrm{J}$ Res Sci Teach 47(9): 1037-1063.

GIBNEY E. 2015. Brazilian science paralysed by economic slump. Nature News, Sep 30, 2015. Available at: http:// www.nature.com/news/brazilian-science-paralysed-byeconomic-slump-1.18458.

GLENDINNING I. 2013a. Impact of Policies for Plagiarism in Higher Education Across Europe. Plagiarism Policies in France. Full Report. Available at: http://plagiarism.cz/ ippheae/files/D2-3-11\%20FR\%20RT\%20IPPHEAE\%20 CU\%20Survey\%20FranceNarrative.pdf.

GLENDINNING I. 2013b. Impact of Policies for Plagiarism in Higher Education Across Europe. Plagiarism Policies in Germany. Full Report. Available at: http://plagiarism.cz/ ippheae/files/D2-3-06\%20DE\%20RT\%20IPPHEAE\%20 CU\%20Survey\%20GermanyNarrative.pdf.

GLIEM JA AND GLIEM RR. 2003. Calculating, interpreting, and reporting Cronbach's Alpha Reliability Coefficient for Likert-Type Scales. Midwest Research-to-Practice Conference in Adult, Continuing, and Community
Education. Available at: https://scholarworks.iupui.edu/ handle/1805/344.

GUPTA N, WEBER C, PEÑA V, SHIPP SS AND HEALEY D. 2013. Innovation policies of Brazil. Institute for Defense Analyses IDA Paper. Available at: https://www.ida.org/ / media/Corporate/Files/Publications/STPIPubs/2014/ ida-p-5039.ashx.

HAMMOND C, KARLIN D AND THIMONIER J. 2010. Creative research science experiences for high school students. PLoS Biol 8(9): e1000447.

HARDMAN F. 2015. Making pedagogical practices visible in discussions of educational quality. Education for All Global Monitoring Report 2015. Available at: http:// unesdoc.unesco.org/images/0023/002324/232449e.pdf.

HASAN I AND TUCCI CL. 2010. The innovation-economic growth nexus: Global evidence. Res Policy 39(10): 12641276.

HOLT EA, FAGERHEIM B AND DURHAM SO. 2014. Online plagiarism training falls short in biology classrooms. CBE Life Sci Educ 13(1): 83-89.

HUDSON P. 2013. Learning to teach in the primary school. New York: Cambridge University Press, 334 p.

INTRONA L, HAYES N, BLAIR L AND WOOD E. 2003. Cultural attitudes towards plagiarism - developing a better understanding of the needs of students from diverse cultural backgrounds relating to issues of plagiarism. Lancaster University. Available at: http://citeseerx.ist. psu.edu/viewdoc/download?rep=replandtype $=$ pdfandd oi $=10.1 .1 .210 .6903$.

JOSEPHSON INSTITUTE, CENTER FOR RESEARCH ETHICS. 2012. The ethics of American youth: 2012. Resource document. Available at: https://charactercounts. org/wp-content/uploads/2014/02/ReportCard-2012DataTables.pdf.

KEMP E AND CHAMBERS I. 2015. Lessons in learning - an effective process for engaging 12- to 14-year-olds in stem cell biology. EMBO Rep 16(1): 7-13.

KHOZA SB. 2015. Can Turnitin come to the rescue: from teachers' reflections? S Afr J Educ 35(4): 1-9.

KNOBEL M. 2014. Brazil scary PISA's results. Available at: https://www.insidehighered.com/blogs/world-view/ brazils-scary-pisa-results.

KRATHWOHL DR. 2002. A revision of bloom's taxonomy: An overview. Theor Pract 41(4): 212-218.

LEMA R, QUADROS R AND SCHMITZ H. 2015. Reorganising global value chains and building innovation capabilities in Brazil and India. Res Policy 44(7): 1376-1386.

LEMONS PP AND LEMONS JD. 2013. Questions for assessing higher-order cognitive skills: it's not just Bloom's. CBE Life Sci Educ 12(1): 47-58.

LIM L. 2011. NPR [National Public Radio]: Plagiarism Plague Hinders China's Scientific Ambition. Available at: http:// www.npr.org/2011/08/03/138937778/plagiarism-plaguehinders-chinas-scientific-ambition. 
LIU SC AND LIN HS. 2014. Primary teachers' beliefs about scientific creativity in the classroom context. Int J Sci Educ 36(10): 1551-1567.

LUJAN HL AND DICARLO SE. 2006. First-year medical students prefer multiple learning styles. Adv Physiol Educ 30:13-16.

MAROCO J AND GARCIA-MARQUES T. 2006. Qual a fiabilidade do alfa de Cronbach? Questões antigas e soluções modernas? Lab Psicol 4(1): 65-90.

MASCITTI I. 2012. Plagiarism or creativity teaching innovation versus stealing. GENIUS project. Progress Report Education, Audiovisual and Culture Executive Agency. Available at: http://eacea.ec.europa.eu/ LLp/project_reports/documents/comenius/all/com mp_518603_genius.pdf.

MAYER RE. 2002. Rote versus meaningful learning. Theor Pract 41: 226-233.

MCCABE DL. 2005. Cheating among college and university students: North-American perspective. Int J Educ Int 1(1).

MCNAIRY MR. 1985. Sciencing: science education in early childhood. Sch Sci Math 85(5): 383-393.

MERONI EC, VERA-TOSCANO E AND COSTA P. 2015. Can low skill teachers make good students? Empirical evidence from PIAAC and PISA. J Policy Model 37(2): 308-323.

NOORDEN RV. 2014. The impact gap: South America by the numbers. Nature 510(7504): 202-203.

NOVAK JD. 2002. Meaningful learning: The essential factor for conceptual change in limited or inappropriate propositional hierarchies leading to empowerment of learners. Sci Educ 86(4): 548-571.

NOVAK JD. 2003. The promise of new ideas and new technology for improving teaching and learning. Cell Biol Educ 2: 122-132.

OECD - ORGANIZATION FOR ECONOMIC COOPERATION AND DEVELOPMENT. 2009a. PISA 2009 Assessment framework key competencies in reading, mathematics and science. Available at: https://www.oecd. org/pisa/pisaproducts/44455820.pdf.

OECD - ORGANIZATION FOR ECONOMIC COOPERATION AND DEVELOPMENT. 2009b. Introduction to OECD's programme for international student assessment (PISA), Take the test: sample questions from OECD's PISA assessments. OECD Publishing, 318 p.

OECD - ORGANIZATION FOR ECONOMIC COOPERATION AND DEVELOPMENT. $2013 \mathrm{a}$. OECD-CCE-Singapore international workshop educating for innovation in Asia: the theory, the evidence and the practice. Available at: http://www.oecd.org/edu/ceri/EDUCERI-CD(2013)6-ENG.pdf.

OECD - ORGANIZATION FOR ECONOMIC COOPERATION AND DEVELOPMENT. 2013b BRAZIL - Country Note -Results from TALIS 2013.
Available at: http://www.oecd.org/brazil/TALIS-2013country-note-Brazil.pdf.

OECD - ORGANIZATION FOR ECONOMIC COOPERATION AND DEVELOPMENT. 2014a. Programme for international student assessment (PISA) PISA 2012 Results: What students know and can do: student performance in mathematics, reading and science (Volume I). Available at: https://www.oecd.org/pisa/ keyfindings/pisa-2012-results-volume-I.pdf.

OECD - ORGANIZATION FOR ECONOMIC COOPERATION AND DEVELOPMENT. 2014b. Programme for international student assessment (PISA) PISA 2012 Results: What makes schools successful? Resources, policies and practices (Volume IV). Available at: https:// www.oecd.org/pisa/keyfindings/pisa-2012results-volume-IV.pdf.

OECD - ORGANIZATION FOR ECONOMIC COOPERATION AND DEVELOPMENT. 2014c. PISA 2012 Results: Ready to Learn. Students' engagement, drive and self-beliefs. Volume III. Paris: OECD. Available at: http://www.oecd.org/pisa/keyfindings/PISA-2012-results-volume-III.pdf.

OECD - ORGANIZATION FOR ECONOMIC COOPERATION AND DEVELOPMENT. 2014d. PISA 2012 Results in Focus. Are 15-year-olds creative problemsolvers? PISA in Focus. Available at: https://www. oecd. org/pisa/pisaproducts/pisainfocus/pisa-in-focus-n38(eng)final.pdf.

OECD - ORGANIZATION FOR ECONOMIC COOPERATION AND DEVELOPMENT. 2014e. Programme for international student assessment (PISA) PISA 2012 Results: creative problem solving: students' skills in tackling real-life problems (Volume V). Available at: http://www.oecd.org/education/pisa-2012-resultsvolumev.htm.

OECD - ORGANIZATION FOR ECONOMIC COOPERATION AND DEVELOPMENT. 2015a. The innovation imperative: contribution to productivity, growth and well-being. OECD Publishing, 268 p. Available at: https://www.oecd.org/publications/the-innovationimperative-9789264239814-en.htm.

OECD - ORGANIZATION FOR ECONOMIC COOPERATION AND DEVELOPMENT. 2015b. Education at a glance 2015: OECD indicators. Available at: http:// download.ei-ie.org/Docs/WebDepot/EaG2015_EN.pdf.

OSBORNE J AND DILLON J. 2008. Science education in Europe: critical reflections. London, UK: Nuffield Foundation. Available at: http://www.nuffieldfoundation. org/sites/default/files/Sci_Ed_in_Europe_Report_Final. pdf.

OSBURN HG. 2000. Coefficient alpha and related internal consistency reliability coefficients. Psychol Methods 5(3): 343-335. 
PAVESI G, SICCARDI A, VIALE G, GRAZIOLI C, CALCIOLARI T, TENCHINI ML AND PLEVANI P. 2008. Hedgehogs, humans and high-school science. The benefits of involving high-school students in university research. EMBO Rep 9(3): 208-211.

PECORARI D. 2003. Good and original: plagiarism and patch writing in academic second-language writing. J Second Lang Writ 12(4): 317-345.

PENNYCOOK A. 1996. Borrowing others' words: text, ownership, memory, and plagiarism. TESOL Quart 30(2): 201-230.

PETERSON RA. 1994. A meta-analysis of Cronbach's coefficient alpha. J Consum Res 21(2): 381-391.

PLAGIARISM TODAY. 2012. Turnitin Analyzes the Spectrum of Plagiarism. Available at: https://www.plagiarismtoday. com/2012/05/10/turnitin-analyzes-the-spectrum-ofplagiarism/.

REDE NACIONAL DE EDUCAÇÃO E CIÊNCIA: NOVOS TALENTOS DA REDE PÚBLICA. 2015. Available at: http://www.educacaoeciencia.net.br/site_on/index. php?option $=$ com_content $\&$ view $=$ article $\&$ id $=1 \&$ Itemid $=$ 107.

ROBERTS T. 2008. Student plagiarism in an online world: Problems and solutions. Hershey, PA: Information Science Reference. 294 p.

ROIG M. 1997. Can undergraduate students determine whether text has been plagiarized? Psychol Rec 47: 113-122.

ROIG M. 2001. Plagiarism and paraphrasing criteria of college and university professors. Ethics Behav 11(3): 307-323.

SANTOS JRA. 1999. Cronbach's Alpha: a tool for assessing the reliability of scales. J Extension 37(2).

SCHÖNBORN KJ AND ANDERSON TR. 2008. Bridging the educational research-teaching practice gap - Conceptual understanding, Part 2: Assessing and developing student knowledge. Biochem Mol Bio Educ 36(5): 372-379.

SCHULTZ D. 2012. From the editor-from lecture halls to the halls of government. J Public Affairs Educ 18(2).

SCHWARTZMAN S AND CHRISTOPHE M. 2009. A educação em ciências no Brasil. Instituto de Estudos do Trabalho e Sociedade. Available at: https://www.abc.org. br/IMG/pdf/doc-210.pdf.

SHANKMAN ML AND ALLEN SJ. 2010. Emotionally intelligent leadership for students: facilitation and activity guide. San Francisco: Jossey-Bass, 464 p.

SIMÕES J. 2012. Rede nacional de educação em ciências forma 14 mil alunos e professores. Sociedade Brasileira para o
Progresso da Ciência. Available at: http://www.sbpcnet. org.br/site/noticias/materias/detalhe.php?id=1636.

SILVA OSF. 2008. Entre o plágio e a autoria: qual o papel da universidade. Rev Bras Educ 13(38): 357-368.

SISTI DA. 2007. How do high school students justify internet plagiarism? Ethics Behav 17(3): 215-231.

SJØBERG S. 2007. PISA and "real life challenges": mission impossible? In Hopmann ST, Brinek G and Retzl M (Eds), PISA zufolge PISA - PISA according to PISA, Berlin: LIT Verlag, p. 203-224.

SLEUWAEGENA L AND BOIARDIA P. 2014. Creativity and regional innovation: Evidence from EU regions. Res Policy 43(9): 1508-1522.

STRAUSS V. 2015. The tower of PISA is badly leaning. An argument for why it should be saved. The Washington Post, March 24, 2015.

SUREDA-NEGRE J, COMAS-FORGAS R AND OLIVERTROBAT MF. 2015. Academic plagiarism among secondary and high school students: differences in gender and procrastination. Comunicar 44(XXII): 103-110.

SUTHERLAND-SMITH W. 2005. Pandora's box: academic perceptions of student plagiarism in writing. J Engl Acad Purposes 4: 83-95.

TAN C. 2015. Beyond rote-memorisation: Confucius' concept of thinking. Educ Philos Theory 47(5): 1-12.

THOMAS EE AND SASSI K. 2011. An ethical dilemma: talking about plagiarism and academic integrity in the digital age. Engl J 100(6): 47-53.

THOMSON REUTERS. 2015. Scimago Journal and Country Rank. Available at: http://www.scimagojr.com/.

TRAN TT. 2013. Is the learning approach of students from the Confucian heritage culture problematic? Educ Res Policy Prac 12(1): 57-65.

TULLEY-PITCHFORD K. 2012. Mouse click plagiarism: Can technology help to fight back? PRHE Journal 6(2): 58-68.

VASCONCELOS SM, SORENSON MM, WATANABE EH, FOGUEL D AND PALÁCIOS M. 2015. Brazilian science and research integrity: Where are we? What next? An Acad Bras Cienc 87: 1259-1269.

WANG C AND GREENWOOD MK. 2015. Chinese nursing students' culture-related learning styles and behaviors: a discussion paper. Int J Nurs Sci 2(3): 253-258.

WORLD ECONOMIC FORUM. 2014. The Global Competitiveness Report 2014-2015. Geneva: World Economic Forum. Available at: http://www3.weforum.org/ docs/WEF_GlobalCompetitivenessReport_2014-15.pdf. 